\title{
Siyasi Partilerin Turizm Politikalarının 2018 Seçim Beyannameleri Kapsaminda İncelenmesi
}

\author{
Examination of Tourism Policies of Political Parties Within the Scope of 2018 Election Declarations
}

\section{Tuna BATUHANa ${ }^{(1)}$}

a Dr. Öğr. Üyesi, Atatürk Üniversitesi, Mimarlık ve Tasarım Fakültesi, Şehir ve Bölge Plânlama Bölümü, Erzurum, Türkiye.

\begin{abstract}
Özet
Bu çalışmada TBMM'de grubu bulunan siyasi partilerin turizm politikaları, partilerin 2018 seçim beyannameleri kapsamında analiz edilmiştir. Siyasi partilerin söylemlerindeki benzerlikler ve farklı1ıkları ortaya konabilmek amaciyla siyasi partilerin turizm hedefleri, pazar hedefleri, turizm türleri, yasal düzenleme önerileri, teşvik ve yatırım önerileri gibi temalar doğrultusunda beyannameler incelenmiştir. Seçim beyannameleri incelendiğinde siyasi partilerin turizm sektörünün ekonomik potansiyelinin farkında oldukları, ancak bu potansiyeli hayata geçirmek için farklı politika öncelikleri belirledikleri görülmektedir. Diğer partilere kıyasla turizm başlığına en geniş alanı ayıran AK Parti seçim beyannamesinde turizm hedefleri en net ve en somut şekilde yer almakta, bu netlik AK Parti'nin diğer turizm politikası önerilerine de yansımaktadır. Muhalefet partileri arasında turizm hedeflerini en net ve somut şekilde ortaya koyan partinin IYYं Parti olduğu görülmektedir. CHP ve MHP seçim beyannamelerinde ise turizm hedefleri dar kapsamlı ve sınırlı şekilde yer almaktadır. CHP ve MHP seçim beyannamelerinin turizm hedeflerini belirlemede yetersiz kalması, her iki partinin diğer turizm politikası önerilerine de olumsuz şekilde yansımış̦tır. Siyasi partilerin turizm politikalarının ve siyasi önceliklerinin güncel gelişmeler ve diğer politika başlıklarındaki gelişmelerden etkilediğini de unutmamak gerekir. Özellikle tüm dünyayı etkilemeye devam eden Covid-19 salgınının en ciddi şekilde etkilediği sektörlerin başında gelen turizmle ilgili siyasi partilerin politika önerilerinin de güncellenmesi gerektiği söylenebilir.
\end{abstract}

Anahtar Kelimeler: 2018 Seçimleri, Siyasi Parti Seçim Beyannameleri, Turizm Politikaları.

\begin{abstract}
In this study, the tourism policies of the political parties with groups in the Turkish Grand National Assembly were analyzed within the scope of the 2018 election declarations of the parties. In order to reveal the similarities and differences in the discourses of political parties, declarations were examined in line with themes such as political parties' tourism goals, market targets, tourism types, legal regulation proposals, incentives and investment proposals. When the election declarations are examined, it is seen that the political parties are aware of the economic potential of the tourism sector, but they set different policy priorities to realize this potential. In the AK Party election declaration, which separates the widest area of tourism compared to other parties, tourism goals are included in the clearest and most concrete way, and this clarity is reflected in the AK Party's other tourism policy proposals. Among the opposition parties, it is seen that the party that sets out its tourism goals most clearly and concretely is the IYI Party. In the CHP and MHP election declarations, tourism goals are included in a narrow and limited way. The inadequacy of the CHP and MHP election declarations in determining tourism targets had a negative impact on the other tourism policy proposals of both parties. It should not be forgotten that tourism policies and political priorities of political parties are affected by current problems and developments in other policy topics. It can be said that the policy recommendations of political parties related to tourism, which is one of the sectors most seriously affected by the Covid-19 pandemic, which continues to affect the whole world, should also be updated.
\end{abstract}

Keywords: 2018 Elections, Political Party Election Declarations, Tourism Policies.
Makale Bilgisi

Geliş Tarihi

27.04.2021

Kabul Tarihi

09.06.2021

Sayı Editörü

Hacer Arslan KALAY

Sorumlu Yazar

Tuna Batuhan

tuna.batuhan@atauni.edu.tr@

\section{Önerilen Atıf:}

Batuhan, T., (2021). Siyasi Partilerin Turizm Politikalarının 2018 Seçim Beyannameleri Kapsamında İncelenmesi. Journal of Academic Tourism Studies, 2(1): 1-11. 


\section{GİRIŞ}

16 Nisan 2017 tarihinde gerçekleşen anayasa değişikliği referandumu ile Cumhurbaşkanlığı Hükümet Sistemine geçilmiştir. Hükümet sistemindeki değişikliğin ardından 3 Kasım 2019'da yapılması gereken seçimlerin yeni sisteme uyumunu hızlandırmak amacıyla daha erken bir tarihte yapılması tartışılmaya başlanmıştır. Bu tartışmalar sonucunda 20 Nisan 2018'de erken seçim önerisi Türkiye Büyük Millet Meclisi'nde kabul edilmiş ve Cumhurbaşkanlığ1 seçiminin ilk turu ile milletvekili seçimlerinin 24 Haziran 2018'de yapılmasına karar verilmiştir.

Seçim kampanyası sürecinde siyasi partilerin vaatlerinin yer aldığı en önemli belgelerden biri seçim beyannameleridir. Seçmenle yapılan bir sözleşme (Terkan, 2010) olarak nitelenen seçim beyannameleri siyasi partilerin gelecekteki politika hedeflerini anlamak açısından önemlidir. Seçmenleri bilgilendirmek ve seçim kampanyalarına yön vermek amacıyla hazırlanan seçim beyannameleri siyasi partilerin farklı politika başlıklarında seçmenlere sundukları vaatleri içermektedir (Rohrbach, 1991; Kalender, 2003; Özkaynar, 2015; Arklan, 2016; Şeşen ve Ertürk, 2017; Arklan ve Tanac1, 2020). Seçim beyannameleri aynı zamanda siyasi partilerin olası hükümet programlarının içeriği hakkında fikir vermeleri nedeniyle önemli birer resmi belge niteliğindedir (Tok, 2012). Bu kapsamda siyasi partilerin seçim beyannamelerinin incelenmesi turizm sektörüne bakış açılarını, sektörel sorun tanımlarını ve politika önceliklerini anlamak açısından önemlidir (Esen ve Uyar, 2011; Aymankuy vd. 2016).

Bu çalışmada 24 Haziran 2018 tarihinde gerçekleşen seçimler sonucunda TBMM'de grup kurmaya hak kazanan siyasi partilerin turizm politikaları, partilerin seçim beyannameleri dikkate alınarak incelenecektir. Siyasi partiler ve cumhurbaşkanı adayları arasında ciddi bir söylem farklılaşması olmaması nedeniyle siyasi parti seçim beyannamelerinin incelenmesi yeterli görülmüştür. Siyasi partilerin seçim beyannameleri partilerin almış oldukları oy oranları ve TBMM'deki milletvekili sayıları esas alınarak Adalet ve Kalkınma Partisi (AK Parti), Cumhuriyet Halk Partisi (CHP), Milliyetçi Hareket Partisi (MHP) ve IYYİ Parti sırasıyla incelenecektir. Halkların Demokratik Partisi (HDP) seçim beyannamesinde turizm başlığında herhangi bir öneri yer almadığından bu parti çalışma dışında tutulmuştur.

Çalışma kapsamında yukarıda sıralanan dört siyasi partinin 2018 seçim beyannameleri turizm politikaları bağlamında analiz edilecektir. Siyasi partilerin söylemlerindeki benzerlikler ve farklılıkları ortaya konabilmek amacıyla belirlenen temalar doğrultusunda bulgular ortaya konulacaktır. Belirlenen temalar: siyasi partilerin turizm hedefleri, pazar hedefleri, turizm türleri, yasal düzenleme önerileri, teşvik ve yatırım önerileri olarak sıralanmaktadır.

\section{SIIYASİ PARTİLERIN SEÇIM BEYANNAMELERINDE TURIZM POLITİKALARI}

\subsection{Adalet ve Kalkınma Partisi Seçim Beyannamesinde Turizm Politikaları}

Adalet ve Kalkınma Partisi'nin “Cumhurbaşkanlığı Seçimleri ve Genel Seçimler Seçim Beyannamesi" başlıklı belgesinde AK Parti iktidarında yapılanlar ve yeni dönemde nelerin yapılmasının planlandığı ayrıntılı olarak açıklanmaktadır (AK Parti, 2018). Beyannamede turizm "İstikrarlı ve Güçlü Ekonomi" başlığı altında ele alınmaktadır. AK Parti seçim beyannamesinde her konu başlığında olduğu gibi turizm başlığında da öncelikle 16 yıllık (2018 itibariyle) iktidar döneminde yapılanlar sıralanmakta, sonrasında ise yeni dönem için ortaya konulan politika önerileri aktarılmaktadır. Turizm alanında 16 yıllık iktidar döneminde "yeni bir vizyonla ülkemizin turizm potansiyelini çok iyi bir biçimde değerlendirerek dünyanın sayılı ülkeleri arasına girme" hedefinin gerçekleştirildiği belirtilmektedir (Ak Parti, 2018: 191). Beyannamede 16 yıllık AK Parti iktidarı döneminde turizm sektörünün uluslararası alanda güçlendiği, turist sayısı ve turizm gelirlerin arttığı sayısal verilerle ifade edilmektedir. Buna göre, 2002 yılında gelen turist sayısı bakımından dünyada 17. sırada olan Türkiye, 2016 yılında 10. sıraya yükselmiştir. 2002 yılında 13,3 milyon yabancı ziyaretçi ülkemize gelirken, 2014 yılında bu rakam 37 milyona yaklaşmıştır. 2002' de 12,4 milyar dolar olan turizm geliri ise, 2014 'te 34 milyar dolara yükselmiştir (AK Parti, 2018: 191). 
AK Parti iktidarı döneminde turizm alanında yapılan diğer düzenlemeler de seçim beyannamesinde ayrıntılı olarak yer almaktadır (AK Parti, 2018). Mevzuat düzenlemeleri çerçevesinde, Türkiye Turizm Stratejisi 2023 ve Eylem Planı ile Turist Rehberliği Meslek Kanunu'nun uygulamaya konulması, turizm sektöründe mesleki eğitimin standardizasyonunu sağlamak üzere belgelendirme sistemi uygulamalarının başlatılması, yayla turizmi gelişimi odaklı Doğu Karadeniz Turizm Master Planının hazırlanması ve uygulamaya konulması gibi başlıklar sıralanmaktadır. Yat turizmini geliştirmek adına 2002'de 8.500 olan yat bağlama kapasitesinin 2017'de 18.261'e ulaştığı, bu kapasitenin 50 bine çıarılmasının hedeflendiği belirtilmektedir. Beyannamede ayrıca doğal ve kültürel değerlerin var olduğu bölgelerde kırsal turizm altyapısının geliştirilmeye devam edileceği belirtilmektedir. Bu kapsamda 2013-2017 yılları arasında toplamda $800 \mathrm{~km}$ yol imalatı ve 13 adet köprü yapım çalışmalarının tamamlandığı Yeşil Yol Projesine yapılan yatırımların gelecek dönemde de devam edeceği ifade edilmektedir. Yeşil Yol Projesinin tamamlanmasıyla Doğu Karadeniz Bölgesindeki 9 ilin önemli yaylaları ve turizm merkezlerinin birbirine bağlanması ve doğayla bütünleşik bir turizm yapısının oluşturulması amaçlanmaktadır.

AK Parti seçim beyannamesinde sağlık turizminin geliştirilmesine yönelik programlar ve turizmin desteklenmesi için sağlanan teşvikler de yer almaktadır (AK Parti, 2018: 192-193). Bu kapsamda AK Parti iktidarı döneminde otel ve lokantacılık hizmetlerinden alınan KDV oranının yüzde $18^{\prime}$ den yüzde $8^{\prime}$ e düşürülmesiyle turizme destek verildiği vurgulanmaktadır. Turizm odaklı çevre düzenlemelerinin yapılması ve altyapının geliştirilmesi gibi yerel yönetim projelerine 20022017 yıllarında toplamda 1,7 milyar TL destek verildiği belirtilmektedir. Turizm sektörüne verilen desteğin bir parçası olarak seyahat acentalarına verilen yakıt desteğinin devam ettiği ve 2017 yılında toplamda 86 seyahat acentasına verilen uçuş desteği miktarının 565 milyon TL olduğu ifade edilmektedir. Ayrıca termal turizm ve kış turizmi yatırımlarında tahsis koşullarının iyileştirildiği, yeşil yıldız belgeli tesis ve işletmelerin tükettikleri elektrik enerjisi bedellerinin bir kısmının bütçeden karşılandığı̆, Kültür ve Turizm Koruma ve Gelişim Bölgelerinde yapılacak turizm yatırımlarının bölge teşviklerinden faydalanabilmesi imkânının verildiği de beyannamede yer alan diğer unsurlardır.

AK Parti her bir şehrimizin uzun vadeli vizyonunda turizme önem verilmesiyle kalkınma hamlesine destek verilmesini hedeflemektedir. Bu bağlamda beyannamede Cazibe Merkezlerini Destekleme Programı çerçevesinde kültür turizmi altyapısının desteklenmesine yönelik projelere 427 milyon TL kaynak aktarıldığı belirtilmektedir. Ulaşım altyapısını geliştirmek amacıyla yapılan Karadeniz ve Akdeniz sahil yolları yatırımlarının turizme de hizmet ettiği vurgulanmaktadır. Her coğrafi bölgede turizm odaklı hedeflerin dile getirildiği beyannamede terör faaliyetlerinin yoğun olduğu bölgelere ve şehirlere yapılan yatırımlarla bu bölgelerin turizm kimliğiyle de anılmasını hedeflemektedir. Ayrıca 23 ören yerine ziyaretçi karşılama merkezi ve çevre düzenlemeleri yapılarak bu ören yerlerinin turizme kazandırıldığı belirtilmektedir (AK Parti, 2018).

AK Parti seçim beyannamesinde 2018 yılına kadar yapılanların yanı sıra gelecek dönemlere yönelik turizm politikası hedefleri de ayrıntılı şekilde sıralanmaktadır (AK Parti, 2018: 193-194). Beyannamede yeni dönem için ortaya konulan turizm hedefi turizm geliri ve turist sayısında ilk beş ülke arasında yer almak ve 50 milyon turist sayısına ulaşmaktır. Bu hedefe ulaşabilmek için turizmde mevcut pazarları güçlendirip gelişen pazarlara özel önem verilmesi, tarihi İpek Yolu'nun canlandırılıp güzergâhta bulunan destinasyonların turizm potansiyellerinin ortaya çıkarılması ve güçlü bir Türkiye markası oluşturmaya yönelik pazarlama ve tanıtım faaliyetlerine hız verilerek tanıtımda destinasyon temelli bir yaklaşımın benimsenmesi gerektiği vurgulanmaktadır.

Turizm türlerinde çeşitliliği artırarak turizm potansiyelini 12 aya yaymayı amaçlayan AK Parti termal, kültür ve doğa temalı turizm gelişim bölgeleri oluşturmayı hedeflemektedir. Ayrıca deniz turizmi, kongre ve fuar turizmi, kış turizmi, golf turizmi, yayla turizmi gibi turizm türlerinin de öncelikli olarak ele alınacağı ifade edilmektedir. Beyannamede sağlık turizmi kapsammnda gelen turist sayısını arttırma hedefi yer almaktadır. Sağlık alanında yapılan yatırımlarla sağlık hizmet sunum kalitesini artırmayı amaçlayan AK Parti, Türkiye' yi sağlık turizminde cazibe merkezi haline getirmeyi hedeflemektedir. Bu kapsamda sağlık turizmi için ülkemize gelen turist sayısının 250 
binden 2 milyona çıkartılması hedeflenmektedir. Termal sağlık turizmine de önem veren beyanname, termal turizmden elde edilen gelir hedefini 2023 yllı için 1 milyar dolar olarak belirlemiştir (AK Parti, 2018).

Eko-turizmin gelişimini de önemseyen AK Parti, bu kapsamda 500 Yeşil Yıldız Belgeli konaklama tesisi inşa edilmesini ve mavi bayraklı plaj sayısının arttırılmasını hedeflemektedir (AK Parti, 2018). Eko-turizmin bölgeler arası gelişmişlik farkını azaltmada ve kırdan kente göçü engellemede etkili olacağının vurgulandığ alınmaktadır. Turizm başlığı altında ayrıca 6 tematik turizm güzergâhının oluşturulması, çevre dostu turizm tesisleri ile sürdürülebilir turizmin yaygınlaştırılması, av turizmi geliştirme bölgeleri oluşturulması ve müzesi olmayan 13 ilimize yeni müzelerin açılması hedefleriyle turizme katkı sağlanması hedeflenmektedir. Son olarak AK Parti gelecek dönemde turizm sektöründe istihdamin arttırılması, turizmin bölgesel kalkınmada önemli bir sektör olması ve Türkiye'nin bireysel turizm ve kitle turizminde önemli bir merkez haline getirilmesi gibi hedefleri turizm politikası hedefleri arasında sıralamaktadır.

\subsection{Cumhuriyet Halk Partisi Seçim Beyannamesinde Turizm Politikaları}

Cumhuriyet Halk Partisi (CHP) seçim beyannamesinde ise turizm sektörü "Bileşik Büyüme İçin Sektörel Öncelikler" başlığı altında yer alan "Hizmetler" alt başlığında "Turizm, Yiyecek ve İçecek Hizmetleri" olarak ele alınmıştır (CHP, 2018: 81-82). Beyannamede ilk olarak Kültür ve Turizm için ayrı bakanlıklar kurulmasını öneren CHP, bu kapsamda Turizm Bakanlığı adıyla ayrı bir örgütlenmenin gerekli olduğunu belirtmektedir. Mevcutta Kültür ve Turizm Bakanlığı ismiyle faaliyet gösteren yapının iki ayrı bakanlığa bölünmesinin gerekçesi beyannamede açıklanmamaktadır. Beyannamede köy turizmi altyapısını geliştirmek amacıyla her yıl 800 köyün turizm köyü ilan edilmesi ve 5 ylllık dönemde her yıl belirlenen 800 turizm köyünde en az 8 bin oda inşa edilmesi hedeflenmektedir. Bu kapsamda olası 5 yıllık iktidar döneminde belirlenen 4 bin turizm köyünde toplamda 40 bin oda inşa edilmesi hedeflenmektedir. CHP dönemsel tanitım programlarıyla sağlık, kültür, gastronomi, inanç, fuar ve kongre turizmi gibi temalara yoğunlaşarak turizmde çeşitliliğin sağlanmasını hedeflemektedir. İç turizmi canlandırmak amacıyla her yıl maddi imkânları kısıtlı olan 100 bin aileye 5 Bin TL yurtiçi turizm çeki desteği verilmesi de vaatler arasında yer almaktadır. CHP beyannamesinde turizm alanında sıralanan diğer vaatler ise Turizm Trenleri Projesi'nin hayata geçirilmesiyle ülke turları düzenlenmesi, turizmde kentleri markalaştırarak rekabet gücünün arttırılması, ürün geliştirme ve lisans desteği sunulması, tarihsel ve doğal zenginliklerinin envanterinin tamamlanıp turizm mekânları haritasının oluşturulmasıdır (CHP, 2018).

Seçim beyannamesinde turizm çalışanları ile ilgili vaatlere de yer veren CHP istihdam garantili eğitim programları geliştirilerek turizm sektöründe çalışanların niteliğinin arttırılmasını hedeflemektedir (CHP, 2018). Turizm sektöründe çalışanların çalışma süreleri ve koşullarının iyileştirilmesi gerektiği de vurgulanmaktadır. Beyannamede ayrıca düşük sezonda turizm işletmeleri çalışanlarının sigorta primlerinde indirim uygulanması vaadi yer almaktadır. Beyannamede ayrıca Çin ve Uzak Doğu'da yatırımların çeşitlendirilmesinde turizm alanında iş birliklerinin etkili olacağını vurgulamaktadır. Ancak bu iş birliği vurgusunda önceliğin turizmden ziyade girişimcilerin iş birliği imkânlarının arttırılmasında olduğu söylenebilir. Son olarak CHP seçim beyannamesinde kalkınma hedefine ulaşmak amacıyla geliştirilen Merkez Türkiye Projesi'nin Beş Kalkınma Kuşağı'ndan birisi olan Mavi Batı Kuşağı'nda turizm faaliyetlerine vurgu yapılmaktadır. Ege, Batı Akdeniz ve İç Anadolu'nun batı illerini kapsayan Mavi Batı Kuşağı'nda turizm faaliyetlerinin katma değerinin arttırılması hedeflenmektedir. Ancak beyannamede bu projenin detayları ve katma değer artışının nasıl sağlanacağı ile ilgili herhangi bir detay yer almamaktadir. 


\subsection{Milliyetçi Hareket Partisi Seçim Beyannamesinde Turizm Politikaları}

Milliyetçi Hareket Partisi (MHP) seçim beyannamesinde turizm sektöründe temel vurgu mevzuat düzenlemeleri ile turizmde yapısal sorunların çözülmesi üzerinedir (MHP, 2018: 103). Bu çerçevede MHP diğer kanunlarda değişiklikleri içeren bir turizm çerçeve kanununun çıkarılmasının yanı sıra özel sektör temsilcilerinin katkısıyla yeni bir "Turizm Strateji Belgesi" ve "Turizm Eylem Planı" hazırlanmasını gerekli görmektedir. MHP özellikle alternatif turizm ürünlerini geliştirecek yatırımcılara dönük teşvikler ve desteklerin arttırılmasını, tarihi ve kültürel varlıkların tanıtımına ağırlık verilip kültür turizminin gelişmesinin sağlanmasını önermektedir. MHP seçim beyannamesinde turizm alanındaki diğer politika önerileri ise sağlık turizminde ülkemizin cazibe merkezi haline getirilmesi, turizmde pazarlama ve tanıtım faaliyetlerine önem verilerek Türkiye'nin turizm potansiyelinin dört mevsim etkin şekilde kullanılması olarak sıralanmaktadır. Son olarak beyannamede Türkiye'nin jeopolitik konumuna vurgu yapılarak lojistik imkânların geliştirilmesi ve bu sayede turizmde rekabetçi avantajın arttırılması gerektiği vurgulanmaktadır.

\subsection{IYİ Parti Seçim Beyannamesinde Turizm Politikaları}

İYİ Parti seçim beyannamesinde turizm politikalarına yer verilen "Turizm" başlıklı bölümde Türkiye'nin turizm gelirleri ve turist sayısı bakımından ilk 5 ülke arasında yer alması ve 5 yıl içerisinde yıllık turizm gelirinin 45 milyar dolara çıkarılması hedeflenmektedir (IYYI Parti, 2018: 8182). Turizm politikası çerçevesinde Milli Turizm Strateji belgesinin hazırlanması, Turizm Yüksek Kurulu ve Turizmi Geliştirme Fonu'nun kurulması ile turizm sektörünün kurumsal yapısının düzenlenmesi önerilmektedir. Çevreci bir bakış açısıyla mevcut turizm destinasyonlarının geliştirilmesi ve yenilerinin belirlenmesi sürecinde turizm yaşam döngüsü ve taşıma kapasitesine dikkat edilmesi gerektiği ifade edilmektedir. Bu kapsamda gerekli yasal düzenlemelerin yapılacağ1 ve hedeflerin buna uygun şekilde belirleneceği vurgulanmaktadır. Hukuki ve idari düzenlemeler yapılarak mevcutta etkin şekilde kullanılmayan ikinci konutların turizm amaçlı kullanılmasının da sağlanacağı belirtilmektedir.

İYİ Parti de AK Parti seçim beyannamesine benzer şekilde ülke tanıtımı yerine, destinasyon tanıtımına ağırlık verilmesini turizm politika stratejisi olarak benimsemektedir. İYİ Parti beyannamesinde turizmde çeşitliliğin sağlanması ve turizmin 12 aya yayılması amacıyla kongre, fuar, sağlik ve gastronomi turizminin teşvik edilmesi, yat ve kurvaziyer turizminin geliştirilmesi gerektiği ifade edilmektedir (İẎ Parti, 2018). Bu kapsamda sağlık turizmi gelirinin yıllık 20 milyar dolara ulaşması hedeflenmektedir. Gastronomi turizminde ise kendi markamızı yaratmak için gerekli planlamaların yapılacağı ifade edilmektedir. İYİ Parti seçim beyannamesinde ayrıca Doğu Anadolu ve Güneydoğu Anadolu bölgelerindeki doğal, tarihi ve kültürel kaynaklar ile inanç turizmi kaynaklarının turizme kazandırılması amacıyla Doğu Anadolu Projesi (DAP) ve Güneydoğu Anadolu Projesi (GAP) Turizm Master Planlarının uygulamaya konulacağı belirtilmektedir. “Doğu Akdeniz Turizm Master Planı” hazırlanarak Doğu Akdeniz'de kıyı turizmi ile birlikte termal, kış, yayla, inanç, doğa ve yat turizmini de kapsayan 100 bin yataklı yeni bir turizm destinasyonunun oluşturulması hedeflenmektedir. Ege Bölgesi'nde özellikle İzmir, Aydın ve Muğla'da turizm yatırımları ve teşviklerin arttırılmasıyla turizm potansiyelinin hayata geçirilmesi amaçlanmaktadır. Genç nüfusu hedefleyen turizm programları oluşturulması da IYİ Parti turizm hedefleri arasında yer almaktadır. Ayrıca turizm beldelerinde yerel yönetimlere bütçe gelirinden yüzde 5 daha fazla pay ayrılmasıyla personel niteliğinin arttırılması önerisi de getirilmektedir.

\section{BULGULAR}

Siyasi partilerin seçim beyannameleri turizm politikaları bağlamında incelendiğinde benzerlikler ve farklılıklar görülmektedir. Bu benzerlik ve farklılıkları analiz etmek amacıyla siyasi partilerin turizm politikaları farklı başlıklarda tablolara aktarılarak karşılaştırılmıştır. Karşılaştırma yapılan başlıklar turizm hedefleri, pazar hedefleri, turizm türleri, yasal düzenleme önerileri, teşvik ve yatırım önerileri olarak sıralanmaktadır. 
Tablo 1: Siyasi Partilerin Seçim Beyannamelerinde Belirtilen Turizm ve Pazar Hedefleri (AK Parti, 2018; CHP, 2018; IYİ Parti, 2018; MHP, 2018)

\begin{tabular}{|c|c|c|}
\hline & Turizm Hedefleri & Pazar Hedefleri \\
\hline AK Parti & $\begin{array}{l}\text { - Uluslararası turizm pazarında önemli bir varış noktası } \\
\text { olmak } \\
\text { - Turizmde uluslararası bir marka haline gelmek } \\
\text { - Turizm gelirleri ve turist sayısında ilk } 5 \text { ülkeden biri } \\
\text { olmak } \\
\text { - } 50 \text { milyon turist hedefine ulaşmak } \\
\text { - Tanitımda destinasyon temelli bir yaklaşım } \\
\text { benimsemek }\end{array}$ & $\begin{array}{l}\text { - Mevcut pazarları korumak } \\
\text { - Çin, Güney Kore, Hindistan, Japonya, } \\
\text { Endonezya ve Türk Cumhuriyetleri ile turizmi } \\
\text { gelisstirmek } \\
\text { - Tarihi İpek Yolu'nu canlandırmak }\end{array}$ \\
\hline CHP & - $\quad$ Turizm faaliyetlerinin ürettiği katma değeri artırmak & $\begin{array}{l}\text { - Çin ve Uzak Doğu ülkeleriyle turizm } \\
\text { alanında iş birliği kurmak }\end{array}$ \\
\hline MHP & $\begin{array}{l}\text { - Tanıtım ve pazarlama konularına etkinlik kazandırmak } \\
\text { - Turizmde rekabetçi avantajı artırmak }\end{array}$ & \\
\hline İYİ Parti & $\begin{array}{l}\text { - Ülke tanıtımı yerine, destinasyonların tanıtımına ağırlık } \\
\text { vermek } \\
\text { - Turizm gelirleri ve turist sayısında ilk } 5 \text { ülkeden birisi } \\
\text { olmak } \\
\text { - Yıllık turizm gelirini } 45 \text { milyar dolara çıarmak }\end{array}$ & - Ege destinasyonunu canlandırmak \\
\hline
\end{tabular}

Siyasi partilerin seçim beyannameleri turizm hedefleri bağlamında değerlendirildiğinde AK Parti ve İẎ̇ Parti'nin net ve somut hedefler belirlediği görülmektedir (Tablo 1). Her iki parti de turizm gelirleri ve turist sayı bakımından dünyada ilk 5 ülke arasına girme hedefini ortaya koymaktadır. İki partinin turizm hedeflerinde benzerlik gösteren bir diğer konu ise ülke tanıtımı yerine destinasyon tanıtımı temelinde bir politikayı benimsemeleridir. AK Parti 50 milyon turist sayısına ulaşmayı hedeflerken, İYI Parti turizm gelirlerinin 45 milyar dolara ulaşması hedefini belirlemiştir. AK Parti turizm hedefleri arasında ayrıca Türkiye'nin uluslararası turizm pazarında önemli bir varış noktası haline gelmesi ve turizmde uluslararası bir marka olması da önemli bir yer tutmaktadır. Turizm hedefleri konusunda CHP ve MHP seçim beyannameleri ise çok daha genel söylemlerle yetinmektedir. CHP'nin turizm sektörü için hedefi turizm faaliyetlerinin ürettiği katma değeri artırmak olarak belirlenirken, MHP tanıtım ve pazarlamaya önem verilmesi ile rekabetçi avantajın arttırılması vurgularını yapmaktadır.

Turizm hedeflerinin daha net ve somut şekilde ifade edilmesi partilerin turizmle ilgili diğer politika önerilerine de yansımaktadır. Bir başka ifadeyle AK Parti ve İYİ Parti seçim beyannamelerinde turizm sektörü ile ilgili öneriler daha kapsamlı ifade edilirken, CHP ve MHP seçim beyannamelerinde turizm önerileri daha sinırlı ve genel niteliktedir. Siyasi partilerin turizmde pazar hedefleri incelendiğinde ise en kapsamlı ifadelerin AK Parti seçim beyannamesinde yer aldığ1 görülmektedir (Tablo 1). AK Parti turizmde mevcut yurtdışı pazarları koruyup tarihi İpek Yolu güzergâhını canlandırarak Çin, Güney Kore, Hindistan, Japonya, Endonezya ve Türk Cumhuriyetleri gibi yeni pazarlarda etkin olmayı amaçlamaktadır (AK Parti, 2018: 193). CHP de benzer şekilde Çin ve Uzak Doğu pazarında etkinliğin artmasını önermekle birlikte bu öneri daha çok girişimcilerin yatırım alanının genişlemesi kapsamında turizm, bilim ve teknoloji alanında iş birliklerinin kurulmasına odaklanmaktadır (CHP, 2018: 127). MHP turizmde pazar hedefleri konusunda beyannamesinde herhangi bir öneriye yer vermezken, İYİ Parti iç pazara odaklanarak Ege bölgesinde turizm faaliyetlerinin canlandırılmasını hedeflemektedir.

Tablo 2: Siyasi Parti Seçim Beyannamelerinde Belirtilen Turizm Türleri (AK Parti, 2018; CHP, 2018; IYİ Parti, 2018; MHP, 2018)

\begin{tabular}{|l|llll|}
\hline & \multicolumn{4}{|l|}{ Turizm Türleri } \\
\hline AK Parti & $\bullet$ Kültür Turizmi & $\bullet$ İnanç Turizmi & \\
& $\bullet$ Sağlık ve Termal Turizm & $\bullet$ Yayla Turizmi & $\bullet$ Kiş Turizmi \\
& $\bullet$ Kongre ve Fuar Turizmi & $\bullet$ Deniz Turizmi & $\bullet$ Golf Turizmi \\
& $\bullet$ Kirsal Turizm & $\bullet$ Yat Turizmi & $\bullet$ Eko-Turizm \\
\hline
\end{tabular}




\begin{tabular}{|c|c|c|}
\hline $\mathrm{CHP}$ & $\begin{array}{ll}\text { - } & \text { Külttür Turizmi } \\
\text { - Sağllk Turizmi } \\
\text { - } \quad \text { Kongre ve Fuar Turizmi }\end{array}$ & $\begin{array}{lll}\text { - İnanç Turizmi } & \bullet & \text { Kirsal Turizm } \\
\text { - Gastronomi Turizmi } & & \\
\text { - Spor Turizmi } & & \end{array}$ \\
\hline MHP & $\begin{array}{ll} & \text { Kültür Turizmi } \\
\text { - } & \text { Sağllk Turizmi }\end{array}$ & \\
\hline İYİ Parti & $\begin{array}{ll}\text { - Sağllk Turizmini } \\
\text { - Inanç Turizmi } \\
\text { - Kongre ve Fuar Turizmi }\end{array}$ & $\begin{array}{l}\text { - } \text { Gastronomi Turizmi } \\
\text { - } \quad \text { Yat ve Kurvaziyer Turizmi }\end{array}$ \\
\hline
\end{tabular}

Siyasi partilerin seçim beyannamelerinde turizm politika önerilerini sıralarken bahsettikleri turizm türleri de farklılık göstermektedir (Tablo 2). AK Parti seçim beyannamesinde 12 farklı turizm türü ile ilgili politika önerileri getirirken bu sayı CHP için 7, İYİ Parti için 5, MHP içinse 2 ile sinırlıdır. Incelenen 4 parti beyannamelerinde ortak olarak yer alan tek turizm türü sağlık turizmidir. AK Parti termal turizmi de sağlık turizmi başlığında bir arada ele almaktadır. AK Parti, CHP ve MHP beyannamelerinde yer alan bir diğer turizm türü kültür turizmi olurken, İYİ Parti'nin beyannamesinde kültür turizmi ile ilgili herhangi bir politika önerisine yer verilmemiştir. AK Parti, CHP ve İYİ Parti beyannamelerinde kongre ve fuar turizmi ile inanç turizmi başlıklarında öneriler sıralanmaktadır. Kırsal turizm AK Parti ve CHP beyannamelerinde, yat turizmi AK Parti ve İYİ Parti beyannamelerinde, gastronomi turizmi ise CHP ve IYI Parti beyannamelerinde vurgulanmaktadir. Ortak turizm türleri beyannamelerde bu şekilde yer alırken ortak başlıklar dışında AK Parti golf, deniz, yayla, kış, doğa ve eko-turizm başlıklarında öneriler getirmektedir (AK Parti, 2018). Ortak turizm türleri dışında CHP spor turizmi başlığına yer verirken, İYİ Parti ise yat ve kurvaziyer turizmini bir arada değerlendirerek politikalar geliştirmiştir. CHP seçim beyannamesinde ayrıca "Turizm Trenleri Projesi" ile Türkiye turları düzenlenmesi önerisine yer verilmiştir. Seçim beyannamesinde turizm başlığına en geniş alanı ayıran AK Parti aynı zamanda en fazla turizm türüne yer veren parti olarak da turizm politikası önerilerini ayrıntılı ve kapsamlı şekilde ortaya koymaktadır. AK Parti beyannamesinde ayrıca termal, doğa ve kültür temalı turizm gelişim bölgeleri kurulması ile 6 tematik turizm güzergâhı oluşturulması önerileri de yer almaktadır. CHP ve IYİ Parti ise AK Parti kadar kapsamlı olmasa da farklı turizm türleri ile ilgili politika önerilerini sıralamaktadır. Seçim beyannamesinde turizm başlığına en az yer veren MHP ise turizm türleri konusunda da çok fazla detaya yer vermemiştir.

Tablo 3: Siyasi Parti Seçim Beyannamelerinde Yasal Düzenleme Önerileri (AK Parti, 2018; CHP, 2018; IYİ Parti, 2018; MHP, 2018)

\begin{tabular}{|c|c|}
\hline & Yasal Düzenleme Önerileri \\
\hline AK Parti & $\begin{array}{l}\text { - Turizm altyapısının gelişmesi için düzenleme ve uygulamalar yapıldı } \\
\text { - Türkiye Turizm Stratejisi } 2023 \text { ve Eylem Planı hayata geçirildi } \\
\text { - Turist Rehberliği Meslek Kanunu uygulamaya koyuldu } \\
\text { - Turizm sektöründe belgelendirme sistemi uygulanmaya başlandı } \\
\text { - Doğu Karadeniz Turizm Master Planını hazırlandı ve uygulamaya koyuldu }\end{array}$ \\
\hline $\mathrm{CHP}$ & $\begin{array}{ll}\text { - } & \text { Kültür ve Turizm alanında ayrı bakanlıklar kurulmalıdır } \\
\text { - } & \text { Turizm bölgelerinde yer alan belediyelerin gelirleri iyileştirilmelidir } \\
\end{array}$ \\
\hline MHP & $\begin{array}{l}\text { - Turizm çerçeve kanunu çıkartılmalıdır } \\
\text { - Yeni bir Turizm Strateji Belgesi ve Turizm Eylem Planı hazırlanarak uygulamaya konulmalıdır } \\
\text { - Teşvik kapsamında alt düzenleyici mevzuat hayata geçirilmelidir }\end{array}$ \\
\hline İYİ Parti & $\begin{array}{l}\text { - Turizm bölgelerinde yer alan belediyelerin bütçe gelirleri arttırılmalıdır } \\
\text { - } \quad \text { Milli Turizm Strateji belgesi hazırlanmalıdır } \\
\text { - Turizm yaşam döngüsü ve taşıma kapasitesini dikkate alacak şekilde mevzuat çalışmaları } \\
\text { yapılmalıdır } \\
\text { - Turizm Yüksek Kurulu ve Turizmi Geliştirme Fonu kurulmalıdır } \\
\text { - } \quad \text { Bölgesel Turizm Master Planları uygulanmalıdır } \\
\text { - } \quad \text { Gençlik ve Bilim Turizmi Stratejisi hazırlanmalıdır }\end{array}$ \\
\hline
\end{tabular}


Turizm alanında yasal düzenleme ihtiyacı iktidar olan AK Parti dışında tüm partiler tarafından dile getirilmektedir (Tablo 3). Muhalefet partilerinin yasal düzenleme ihtiyacı vurgusuna karşın AK Parti ise kendi iktidarı döneminde yapılan yasal düzenlemeleri sıralamaktadır. AK Parti kendi iktidarı döneminde turizm altyapısını geliştirmeye hizmet eden önemli düzenlemelerin yapıldığını ve uygulamaya geçirildiğini vurgulamaktadır. AK Parti seçim beyannamesinde turizm sektörü için önemli bir yol haritası niteliğindeki Türkiye Turizm Stratejisi 2023 ve Eylem Planı ile Turist Rehberliği Meslek Kanunu'nun uygulamaya konulduğu ifade edilmektedir. Yasal düzenlemeler bağlamında ayrıca Doğu Karadeniz Turizm Master Planı'nın hazırlanıp uygulamaya konulmasının yayla turizminin gelişmesine önemli katkı sağlayacağ 1 dile getirilmektedir. Son olarak belgelendirme sistemi uygulamalarının başlamasıyla turizm sektöründe niteliğin ve mesleki eğitim standartlarının arttırılmasına katkı sağlandığı belirtilmektedir.

Öte yandan turizm alanında yasal düzenleme ihtiyacını en kapsamlı şekilde ifade eden İẎ Parti yapılacak mevzuat çalışmalarında turizm yaşam döngüsü ve taşıma kapasitesine dikkat edileceğini vurgulamaktadır (İYİ Parti, 2018). İẎ̇ Parti öncelikle kamu sektörü ile birlikte özel sektörün de destek vereceği Milli Turizm Strateji Belgesi hazırlanmasını gerekli görmektedir. Ayrıca Gençlik ve Bilim Turizmi Stratejisi hazırlanarak yıllık 5 miyar TL gelir elde edilmesi hedeflenmektedir. Bu düzenlemelere ek olarak İYİ Parti Turizm Yüksek Kurulu ve Turizmi Geliştirme Fonu kurulmasını, Bölgesel Turizm Master Planlarının uygulanmasını önermektedir. Turizm beldelerine sahip yerel yönetimlere merkezi bütçeden $\% 5$ fazla pay aktarılması da İYİ Parti önerileri arasındadır. CHP de IYẎ Parti'nin önerisine benzer şekilde turizm bölgelerindeki yerel yönetimlerin gelirlerinin özellikle yaz aylarındaki yoğunluk dikkate alınarak iyileştirilmesi gerektiğini vurgulamaktadır. Yasal düzenlemeler kapsamında CHP ayrıca mevcuttaki Kültür ve Turizm Bakanlığı yapılanmasının ikiye bölünerek turizm ve kültür için ayrı bakanlıklar kurulmasını önermektedir. MHP ise uygulamaya konulan Turizm Strateji Belgesi ve Turizm Eylem Planı'nı yeterli bulmayarak yeniden hazırlanmasını istemektedir. MHP ayrıca turizmle ilgili birçok kanunda değişiklikleri de kapsayacak şekilde turizm çerçeve kanununun çıkarılmasını ve bu kapsamda alt mevzuatta da düzenlemelerin yapılmasını gerekli görmektedir.

Tablo 4: Siyasi Parti Seçim Beyannamelerinde Teşvik ve Yatırım Önerileri (AK Parti, 2018; CHP, 2018; IYİ Parti, 2018; MHP, 2018)

\begin{tabular}{|c|c|}
\hline & Teşvik ve Yatırım Önerileri \\
\hline AK Parti & $\begin{array}{ll}\text { - Sağlanan çeşitli teşviklerle turizm desteklendi: } \\
\text { ○ Otel ve lokantacılık hizmetlerinde KDV oranı yüzde 8'e düşürüldü } \\
\text { ○ Yerel yönetim projelerine 1,7 milyar TL kaynak aktarıldı } \\
\text { ○ Seyahat acentalarına yakıt desteği verildi } \\
\text { ○ Yatırımların tahsis koşulları iyileştirildi } \\
\text { ○ Turizm yatırımlarında bölge teşviki imkânı verildi }\end{array}$ \\
\hline $\mathrm{CHP}$ & $\begin{array}{l}\text { - } \text { Köy turizmi altyapısı geliştirilmelidir } \\
\text { - } \quad \text { Ray Otobüsü sistemi kurulmalıdır } \\
\text { - } \text { GAP bölgesinde kara yolları ağları modernize edilmelidir } \\
\text { - Her yıl } 100 \text { bin aileye } 5 \text { Bin TL yurtiçi turizm çeki desteği verilmelidir } \\
\text { - } \quad \text { Emeklilere uygun ücretlerle gezi ve tatil olanağı sunulmalıdır }\end{array}$ \\
\hline MHP & - Yatırımcılara teşvik ve destek sağlanmalıdır \\
\hline
\end{tabular}

Turizm alanında teşvik ve yatırım önerileri başlığında ise IYYİ Parti dışında tüm partilerin görüşleri seçim beyannamelerinde yer almaktadır (Tablo 4). AK Parti kendi iktidarları döneminde sağlanan teşviklerle turizmin desteklendiğini ifade etmektedir. Bu bağlamda otel ve lokantacılık hizmetlerinden alınan KDV oranının yüzde $18^{\prime}$ den yüzde 8 'e düşürüldüğü, turizm odaklı yerel yönetim projelerine 2002-2017 yıllarında toplamda 1,7 milyar TL kaynak aktarıldığı ifade edilmektedir (AK Parti, 2018: 192). Ayrıca seyahat acentalarına yakıt desteğinin devam ettiği, kış turizmi ve termal turizme yönelik yatırımların tahsis koşullarının iyileştirildiği, yeşil yıldız belgeli 
tesis ve işletmelerin enerji harcamalarının bir kısmının bütçeden karşılandığı ve bazı turizm yatırımlarının bölge teşviklerinden yararlandığı vurgulanmaktadır. CHP ise ulaşım altyapısının yeterli olmadığı gerekçesiyle köylerde altyapının geliştirilmesini (köy turizmi), kırsal ve turizm bölgelerinde Ray Otobüsü sistemlerinin kurulmasını ve GAP bölgesi turizm merkezlerindeki karayolu ağlarının modernize edilmesini ve yeni yatırımlar yapılmasını önermektedir. CHP ayrıca iç turizmi teşvik amacıyla her yıl imkânları kısıtlı 100 bin aileye 5 Bin TL yurtiçi turizm çeki desteği verileceği ve emeklilere uygun fiyatlarla tatil yapma ve gezme olanağı sağlanacağ bulunmaktadır. MHP'nin beyannamesinde yer alan tek önerisi ise alternatif turizm ürünleri geliştiren yatırımcılara teşvik ve destek sağlanmasıdır (MHP, 2018: 103).

\section{SONUÇ ve DEĞERLENDİRME}

Bu çalışma kapsamında incelenen 4 siyasi partinin seçim beyannamelerinde turizm sektörü ile ilgili ortaya konulan temel yaklaşım Türkiye'nin turizm potansiyelinin en etkin şekilde değerlendirilmesi ile turizm gelirlerinin arttırılması gerektiği yönündedir (AK Parti, 2018; CHP, 2018; IYYİ Parti, 2018; MHP, 2018). Siyasi partilerin bu ortak tespiti turizm sektörünün ekonomik potansiyelinin her siyasi parti tarafından dikkate alındığını göstermesi açısından önemlidir.

AK Parti seçim beyannamesinde turizm hedeflerinin net ve somut bir şekilde ifade edildiği, beyannamede yer alan diğer turizm politikası önerilerinin de bu hedeflere ulaşabilmek için kapsamlı ve somut şekilde detaylandırıldığı görülmektedir. Diğer partilere kıyasla turizm başlığına en geniş alanı ayıran AK Parti seçim beyannamesinde (Ak Parti, 2018) 18 yıllık iktidar döneminde turizm alanında yapılanların yanı sıra, gelecek dönemlere yönelik turizm politikası hedeflerine de yer verilmiştir. AK Parti hükümetleri döneminde turizm alanında şu ana kadar yapılmış olanlardan yola çıkarak, turizm politikası önerileri beyannamede birbirini tamamlayan ve doğrulayan bir içerikte sunulmuştur. Bu sayede AK Parti'nin geçmişte yaptıkları ile gelecek dönem turizm politikası hedefleri arasında tutarlılık ve bütünlük sağlanmış, turizm politikası hedefleri diğer partilere kıyasla daha somut ve öngörülebilir hale gelmiştir. Bu durum AK Parti'nin iktidar olma avantajını seçim beyannamesindeki vaatleriyle uyumlaştırdığını ve kendi iktidarı döneminde uygulanan turizm politikalarının arkasında durduğunu da göstermektedir.

AK Parti seçim beyannamesinde yer alan önerilerin aksine muhalefet partilerinin önerilerinin daha soyut ve genel nitelikli olduğu söylenebilir. Muhalefet partileri arasında turizm hedeflerini en net ve somut şekilde ortaya koyan parti İYİ Parti' dir. İYİ Parti turizm alanında yasal düzenleme ihtiyacını da en kapsamlı şekilde seçim beyannamesinde ele alan muhalefet partisidir. CHP ve MHP seçim beyannamelerinde ise turizm hedefleri dar kapsamlı ve sinırlıdır. CHP ve MHP seçim beyannamelerinin turizm hedeflerini belirlemede yetersiz kalması, her iki partinin diğer turizm politikası önerilerine de olumsuz şekilde yansımıştır.

Öte yandan siyasi partilerin politikalarını belirleyen ve yönlendiren tek değişkenin seçim beyannameleri olmadığını, siyasi partilerin beyannamelerinde yer alan politika önerileriyle gerçekleştirdikleri uygulamalar arasında ciddi farklar olduğunu da unutmamak gerekir. Siyasi partiler dünyada ve Türkiye' de ortaya çıkan gelişmelere ve değişen şartlara bağlı olarak politika önerilerini değiştirmekte, güncellemekte ve bazı durumlarda politika önerilerinden vazgeçebilmektedirler. Bu bağlamda seçmenleri ikna etmek amaçlı vaatlerin yer aldığı belgeler (Balc1, 2008) olan seçim beyannamelerini inceleyerek siyasi partilerin turizm politikalarını kapsamlı bir şekilde anlamak yeterli olmayabilir.

$\mathrm{Bu}$ çalışma kapsamında siyasi partilerin sadece 2018 seçim beyannamelerinin incelenmiş olması da siyasi partilerin turizm politikası söylemlerinin zamansal değişimini ve politika tutarlılığını ölçmeye imkân vermemektedir. Siyasi partilerin diğer seçim beyannameleri, söylemleri, uygulamaları ve çalışmaları uzun vadede bütüncül şekilde incelendiğinde farklı sonuçlar ortaya çıkabilir. Ayrıca seçmenle siyasi parti arasında bir sözleşme (Terkan, 2010) niteliği taşısa da seçim beyannamelerinin partiler adına bağlayıcılığının olmaması, siyasi kampanya süreçlerinde ortaya konulan vaatlerle pratikte uygulanan politikaların farklılık gösterebilmesi gibi unsurlar da 
beyannamelerde yer alan politika önerilerinin inandırıcılığını, tutarlılığını ve samimiyetini sorgulatan önemli etkenlerdir (Aymankuy vd. 2016; Tok, 2012).

Son olarak dinamik bir alanı temsil eden turizmin birçok politika başlığı ile doğrudan ilişkili olduğu unutulmamalıdır (Olalı, 1990). Diğer politika alanlarında ortaya çıkacak olumlu-olumsuz her gelişme kırılgan yapıdaki turizm sektörünü ve ertelenebilir nitelikteki turizm talebini etkilemektedir (Blake ve Sinclair, 2003; Pforr ve Hosie, 2008). Bunun en somut örneği 2020 y1lında ortaya çıkan ve tüm dünyayı derinden etkilemeye devam eden Covid-19 salgın sürecidir (WTTC, 2020). 2020 yılı sonu itibariyle dünya genelinde turizm ve seyahat sektöründe çalışan 120 milyondan fazla kişinin ve ailesinin salgından olumsuz şekilde etkilendiği ve turizm sektörünün 5.5 trilyon dolardan fazla zarara uğradığı tahmin edilmektedir (WTTC, 2020). Covid-19 salgını ile birlikte hemen her politika başlığında ortaya koyulan gelecek önerileri ve beklentiler salgın sonrasında gözden geçirilmek zorunda kalınmıştır. Salgından en ciddi şekilde etkilenen sektörlerin başında gelen turizm ile ilgili siyasi partilerin politika önerilerinin de güncellenmesi ve mevcut duruma uyumlu hale getirilmesi gerektiği söylenebilir.

\section{Kaynakça}

Adalet ve Kalkınma Partisi. (2018). Adalet ve Kalkınma Partisi Cumhurbaşkanlığı Seçimleri ve Genel Seçimler Seçim Beyannamesi. Güçlü Meclis, Güçlü Hükümet, Güçlü Türkiye: Yaparsa Yine Ak Parti Yapar. 4 Haziran 2020 tarihinde https://www.aa.com.tr/uploads/userFiles/c09e217d-a61f-47f8-a355ddf8004cfef9/Beyanname23May\%C4\%B1s18-icSayfalar.pdf adresinden erişildi.

Arklan, Ü. (2016). Seçmenlerin Seçim Kampanyalarından Yararlanma Amaçları: 7 Haziran 2015 Genel Seçimleri Sivas Araştırması. Ş. Balıı (Ed.), 7 Haziran'dan 1 Kasım'a Türkiye'de Siyasal İletişim Uygulamaları içinde (109-156). Konya: Literatürk Academia Yayınları.

Arklan, Ü. ve Tanacı, F. (2020), Seçim Kampanyalarına Beyannameler Bağlamında Bir Bakış: 31 Mart 2019 Yerel Seçimleri Örneğinde Karşılaştırmalı Bir İnceleme, Süleyman Demirel Üniversitesi Vizyoner Dergisi, 11 (26), 1-29.

Aymankuy, Y., Demirbulat, Ö. G. Ve Aymankuy, Ş. (2016), Türkiye'de Siyasi Partilerin Seçim Beyannamelerinde Turizmin Yeri - Haziran 2015 Genel Seçimleri Örneği, Mehmet Akif Ersoy Üniversitesi Sosyal Bilimler Enstitüsü Dergisi, 8 (16), 292-302.

Balcı, Ş. (2008). Medya ve siyaset ilişkilerinde siyasal reklam: Güncel örnekler üzerinden bir değerlendirme. Z. Damlapınar (Ed.), Medya ve siyaset içinde (209-244), Konya: Eğitim Kitabevi Yayınları.

Blake, A. ve Sinclair, M. T. (2003), Tourism Crisis Management: US Response to September 11, Annals of Tourism Research, 30 (4), 813-832.

Cumhuriyet Halk Partisi. (2018). Cumhuriyet Halk Partisi Seçim Bildirgesi: Millet İçin Geliyoruz. 4 Haziran 2020 tarihinde http://secim2018.chp.org.tr/files/CHP-SecimBildirgesi-2018-icerik.pdf adresinden erişildi.

Esen, Ş. ve Uyar, H. (2011), Siyasi Partilerin Turizm Sektörüne Yönelik Rekabet Stratejileri: 2011 Genel Seçim Beyannameleri Üzerine Bir Araştırma, 12. Ulusal Turizm Kongresi, Akçakoca Turizm İşletmeciliği ve Otelcilik Yüksekokulu, Akçakoca/Düzce, 341-348.

Halkların Demokratik Partisi. (2018). Halkların Demokratik Partisi Seçim Bildirgesi. 4 Haziran 2020 tarihinde https://www.hdp.org.tr/tr/materyaller/24-haziran-secimleri/11967 adresinden erişildi.

İyi Parti. (2018). İyi Parti Seçim Beyannamesi: Milletimizle Sözleşme: Toplumda Birlik, Ekonomide Güven, Yönetimde Liyakat. 4 Haziran 2020 tarihinde http://iyiparti.org.tr/assets/pdf/secim_beyani.pdf adresinden erişildi.

Kalender, A. (2003), Seçmenin Karar Sürecinde İletişim Araç ve Yöntemlerinin Önemi Üzerine Bir Araştırma, Selçuk İletişim, 2 (4), 30-41. 
Milliyetçi Hareket Partisi (2018). Milliyetçi Hareket Partisi 24 Haziran 2018 Milletvekili Genel Seçimi Seçim Beyannamesi: Milli Diriliş Kutlu Yükseliş. 4 Haziran 2020 tarihinde https://www.aa.com.tr/uploads/userFiles/c09e217d-a61f-47f8-a355 ddf8004cfef9/MHP_secim_beyannamesi.pdf adresinden erişildi.

Olalı, H. (1990). Turizm Politikası ve Planlaması. İşletme İktisadi Enstitüsü yayınları, No: 122.

Özkaynar, K. (2015), Siyasi Partilerin 2011 ve 2015 Yılı Seçim Beyannamelerine Bakış: Bir Doküman İncelemesi ve İçerik Analizi Çalışması, Akademik Sosyal Araştırmalar Dergisi, 3 (17), 439-452.

Pforr, C. Ve Hosie, P. J. (2008), Crisis Management in Tourism: Preparing for Recovery, Journal of Travel and Tourism Marketing, 23 (2-4), 249-264.

Rohrbach, S. (1991). Elections In The Media Age: An Analysis Of Political Party Platforms And TV News Transcripts Covering The 1984 American Election Campaign. Political Science Publication, Essex.

Şeşen, E. ve Ertürk, K. Ö. (2017), Türkiye'de 1990 Sonrası Çevre Politikalarının Seçim Beyannamelerine Yansımaları, Selçuk İletişim, 10 (1), 188-215.

Terkan, B. (2010), Siyasi Partilerin Kadına İlişkin Söylem Ve Politikaları (AKP ve CHP Örneği), Selçuk İletişim, $6(2), 115-136$.

Tok, T. N. (2012), Türkiye'deki Siyasal Partilerin Eğitim Söylemleri ve Siyasaları, Kuram ve Uygulamada Eğitim Yönetimi, 18 (2), 273-312.

WTTC (2020). 100 Million Jobs Recovery Plan Final Proposal. 29 Mayis 2021 tarihinde https://wttc.org/Portals/0/Documents/Reports/2020/100\%20Million\%20Jobs\%20Recovery\%20Plan .pdf?ver=2021-02-25-183014-057 adresinden erişildi. 